УДК [903’12.21:902.01](477.81)“632”

https://doi.org/10.15407/archaeologyua2020.03.008

Maier A., Stupak D., Vasyliev P., Khoptynets I., Tkach V. *

\title{
ON THE TECHNOLOGICAL AND TYPOLOGICAL INTEGRITY OF ASSEMBLAGES FROM NORTH-WESTERN UKRAINE BETWEEN 35 AND 30 KYR CAL BP
}

The sites of Myrohoshcha I, Hriadky, Zhorniv, and Chervonyi Kamin are located in the central part of the Volhynian loess Plateau in north-western Ukraine. The assemblages, known from excavations and surface collections, exhibit a number of characteristics, which are traditionally seen to be indicative of different periods. Therefore, these assemblages were thought to represent palimpsests of Middle and Upper Paleolithic occupations. In 2018, these assemblages have been reviewed. At Myrohoshcha I, the old trench could be located and new excavations were carried out. In this paper, the results of the excavations from 2018 as well as preliminary notes on the campaign of 2019 are presented and the technological and typological characteristics of the assemblages are discussed. By demonstrating the repeated and consistent combination of specific and characteristic features, it is considered that these assemblages are neither mixed nor representative of a long settlement history. Instead, they rather seem to represent a coherent set of features, probably characteristic for the period roughly between 35 and $30 \mathrm{kyr}$ cal BP.

K e y w o rds: Unifacial and bifacial tools, flat flake cores, narrow-face cores, blade cores, pointed blades

* MAIER Andreas - Ph.D., Junior professor, Institute for Prehistoric Archaeology, University of Cologne, Germany, ORCID 0000-0002-5021-3341,a.maier@uni-koeln.de STUPAK Dmytro - Ph.D., Research Fellow in the Stone Age Archaeology Department of the Institute of Archaeology, the National Academy of Sciences of Ukraine, ORCID 0000-0002-0809-2179, stupak17@ukr.net VASYLIEV Pavlo - Junior Research Fellow in the Department «Archaeological Museum» of the Institute of Archaeology, the National Academy of Sciences of Ukraine, ORCID 0000-0002-9800-8152, pavlikmorozovski@gmail.com

KHOPTYNETS Ivan - Senior Research Fellow in the Department of Archaeology and Monumentology, State Scientific Center for Protection of Cultural Heritage from Industrial Disasters, ORCID 0000-0003-1143785X,vanhopta@ukr.net

TKACH Vitalii - Fellow worker of the Volhynian Paleolithic Expedition, Dubno, Ukraine, ORCID 00000002-5581-3784,duben@ukr.net

(c) MAIER A., STUPAK D., VASYLIEV P., KHOPTYNETS I., TKACH V., 2020

\section{Introduction}

The historic region of Volhynia is situated at about $50^{\circ}$ northern latitude in today's north-western Ukraine, parts of south-eastern Poland, and south-western Belarus. It roughly corresponds to the extent of the Volhynian loess plateau, a gently rolling landscape stretching circa $60 \mathrm{~km}$ from north to south, roughly between the Prypiat marshes and the Podolian Upland and $300 \mathrm{~km}$ from eastern Poland to Novohrad-Volynskyi in Ukraine. The loess plateau is subdivided into smaller units by rivers flowing predominantly north, such as the Western Bug, Styr and Horyn, the two latter joining the Prypiat, which itself is a tributary to the Dnieper. Roughly in the centre of the Volhynian loess landscape, in the vicinity of the cities of Rivne and Dubno, several sites are located in a relatively small area of about $900 \mathrm{~km}^{2}$ (fig. 1).

An important aspect of Volhynia's natural resources is the occurrence of amber as well as many outcrops of high-quality raw material, so-called Volhynian flint, present in the marl underlying the loess deposits, which, in turn, can reach a thickness of about 10 m (Пясецький 1999, с. 8).

Archaeological research in this region dates back to the beginning of the 20 century. Unfortunately, many of the early finds, including human bones, were lost during World War I and II. To date, about 30 Paleolithic sites are known between the Styr and Horyn rivers. Several of these sites have been known from surface collections and were subject to numerous test trenches and extensive excavations. The majority of these excavations as well as the archaeological classification of finds have been carried out by V. K. Piasetskyi, a geologist from the region (Пясецький 2009), as well as archaeologists V. K. Savych (1975) and D. Yu. Nuzhnyi (2015). 


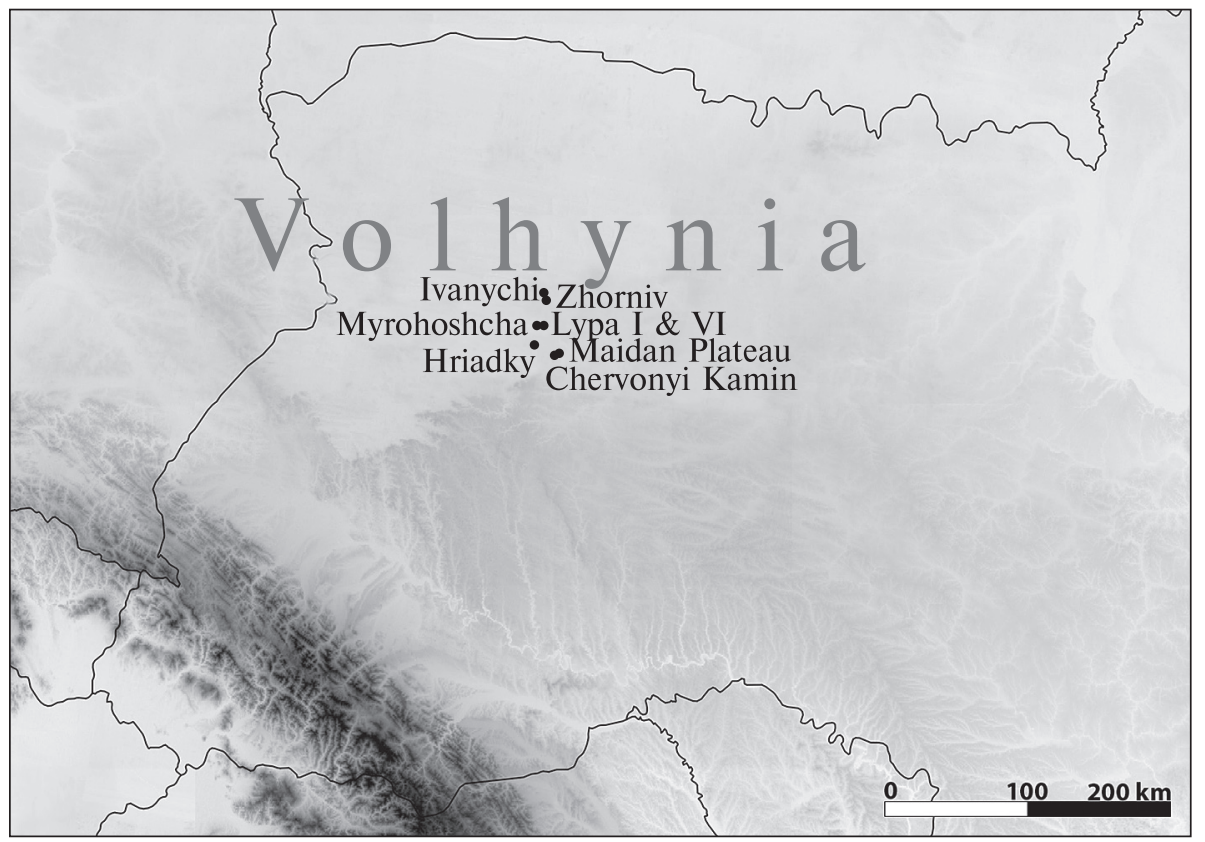

Fig. 1. The location of sites in the region of Volhynia

Based on his work on the region, M. Ya. Rudynskyi claimed a certain idiosyncrasy of the Paleolithic in Volhynia, which he described as a specific phenomenon that has no analogies in neighboring territories. The characteristic feature of this «industry of the Lypa type» is the usage of flakes as main blanks for all types of tools. Additionally, M. Ya. Rudynskyi noted a wide range of technological concepts applied in this industry, including also typical Upper Paleolithic blade production. At the time of his research, he could not give an exact chronological definition of this phenomenon (Рудинський 1952, c. 143-154). This idea of a somewhat independent facies has also been pursued by M. I. Ostrovskyi. With reference to the material he had discovered between 1930s and 1960s mainly at the surface or in unclear stratigraphic positions near the village of Lypa, at the sites of Myrohoshcha I and Chervonyi Kamin, he described together with G. P. Grigoriev the «Lypa local culture» (Островский, Григорьев 1966, c. 9). The most important aspects of this category were artifacts considered as displaying «Aurignacian features», such as carinated scrapers, and cores with a narrow flaking surface. In subsequent publications, Grigoriev reified this category further (Григорьев 1968; 1970). This taxonomic attribution, however, has met with criticism. In the light of his excavations at Lypa I and Lypa VI, Savych rejects the idea of the «Lypa local culture» (Савич 1975).

At the sites of Zhorniv, Myrohoshcha I, and Hriadky, V. K. Piasetskyi dug numerous test trenches and conducted excavations on larger areas. Besides carinated cores and blade cores, he also found unifacially and (in few numbers) bifacially worked tools on large flakes together with large and flat flake cores, more or less resembling Levallois cores. Considering both systems of blank production as unreltaed per se, he assigned the blade and bladelet cores to the Aurignacian and the flake cores together with the surface shaped pieces to the Mousterian (Пясецький 1999; 2009, с. 87-103). Including also the surface collections from Chervonyi Kamin and Ivanychi, V. K. Piasetskyi proposed a continuous occupation of the region from the Mousterian (Zhorniv), over an early (Ivanychi) and late (Chervonyi Kamin) Aurignacian, as well as different earlier (Zhorniv, Ivanychi, Chervonyi Kamin) and also later (Myrohoshcha I and Hriadky) Gravettian occupations (Пясецький 1999). Similar to M. I. Ostrovskyi and Grigoriev (1966), Piasetskyi saw a cultural development from Ivanychi over Chervonyi Kamin to Myrohoshcha I as «successive stages of Lypa Paleolithic culture» (Пясецький 1999, с. 8). The postulated differences between these allegedly successive assemblages are probably for the most part the result of the selection process conducted by V. K. Piasetskyi. This is particularly the case for artifacts, which he considered to belong to a Levallois-Mousterian. Through this systematic partitioning of the collections, the original character of the assemblages was altered, and artifact combinations were ex post facto adjusted to the expectations created by the classic Western European sequence.

Piasetskyi's views and the idea of the Lypa culture were criticized by A. S. Sytnyk, who argued in 


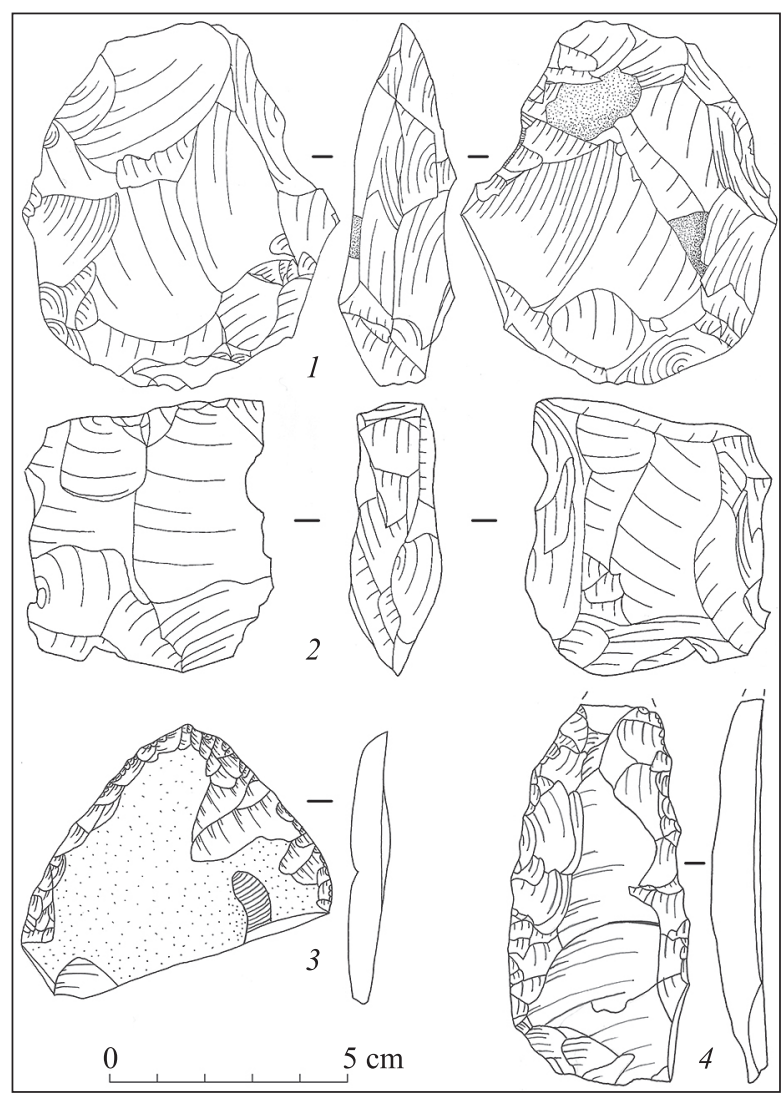

Fig. 2. Artifacts from V. K. Piasetskyi's surface collection and test trench at Myrohoshcha I. 1-2 - flat flake cores; 3 - scraper on a large, thin cortical flake; 4 - blade with convergent lateral retouches

favor of different and chronologically successive cultural phenomena (Ситник 2010, с. 113-137).

The question thus arises as to what extent the proposed archaeological sequence can be corroborated or refuted by a review of the assemblages in question. In the following, a review of the technological and typological characteristics of Myrohoshcha I, Hriadky, Zhorniv, and Chervonyi Kamin is presented. By emphasizing their strong similarities and repeatedly co-occurring traits, we aim at demonstrating that these assemblages constitute coherent artifact associations. They thus do not seem to be the remains of a longer sequence of consecutive occupations, but rather represent a comparatively short-lived phenomenon of only few millennia at most. Based on the findings of the new excavations at Myrohoshcha I, which are roughly in agreement with an older ${ }^{14} \mathrm{C}$-date from Zhorniv, these assemblages seem to date approximately between 35 and $30 \mathrm{kyr}$ cal BP.

\section{Material and Methods}

The assemblages of Myrohoshcha I, Hriadky, Zhorniv, and Chervonyi Kamin obtained by
M. I. Ostrovskyi and, above all, V. K. Piasetskyi, are stored at the Rivne Regional Museum, where they are accessible for analysis.

Myrohoshcha I is situated on a slope oriented to the north. An artifact assemblage of 218 pieces was collected on a small area on the modern surface (Пясецкий 1999, с. 99-104). Additionally, a test trench was dug into the slope sediments. From this trench, only a small number of artifacts was recovered (Пясецький 2009, с. 110-112). Recently, the test trench could be localized and extended by three of the authors (P. Vasyliev, I. Khoptynets, V. Tkach). This renewed excavation so far brought about 5536 artifacts from 10 cultural layers. In contrast to the previous excavations, the sediment has been wet-sieved and all finds were documented three-dimensionally.

Hriadky was excavated by V. K. Piasetskyi in 31 test trenches and four larger excavations, covering together an area of ca. $1200 \mathrm{~m}^{2}$. The artifacts have been found in a sandy deposit roughly $50 \mathrm{~cm}$ below the modern surface and comprise about 2058 pieces (Пясецький 2009, с. 122, 123).

From the site of Zhorniv, 7 find spots are reported, whereof the spots 3 and 4 , separated from each other by ca. $100 \mathrm{~m}$, are most important (Пясецький 2009). Together, excavations at the spots 3 and 4 brought an artifact assemblage of 2191 items.

The assemblage of Chervonyi Kamin $(n=2502)$ is only known from surface finds (Пясецький 2009 , c. 92-102), and thus the internal integrity of the collection cannot be established with certainty.

The assemblages were analysed with regard to their typological and technological characteristics using attribute analysis and chaîne opératoire reconstruction. Since raw material is available in abundance, the collections often have the character of workshop assemblages. They thus comprise a lot of chronologically and chorologically rather insensitive blanks and debitage pieces, often obtained in non-standardized, opportunistic fashion. To account for this fact, the assemblages were first examined in their entirety. In a second step, the recording of attributes focused on sub-samples of diagnostic pieces, which are considered representative for the technological and typological spectrum.

\section{Results}

Myrohoshcha I: surface collection and trenches by V. K. Piasetskyi. The material from the surface collection and V. K. Piasetskyi's trench are technologically and typologically indistinguishable. From this assemblage, attribute recording was done for a total of 96 artifacts (fig. 2-4). 


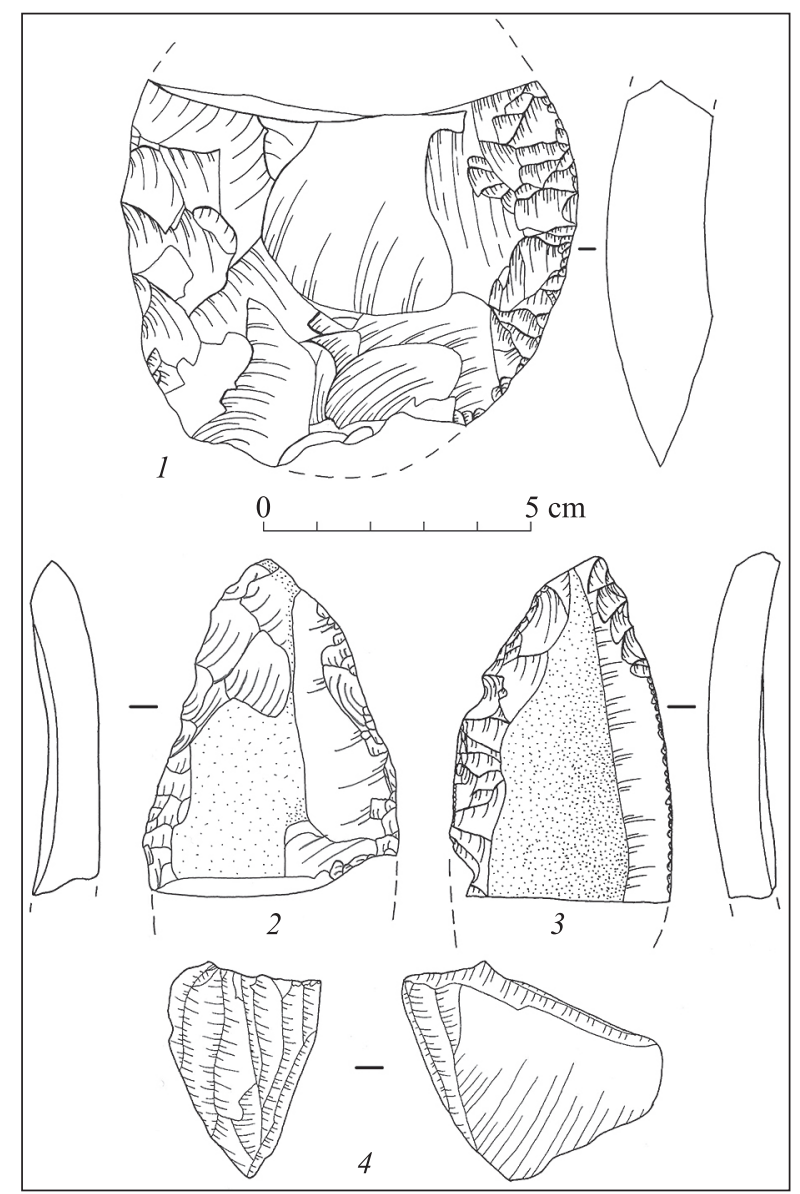

Fig. 3. Artifacts from V. K. Piasetskyi's surface collection and test trench at Myrohoshcha I. 1 - large flake with invasive, unifacial retouch; $2-3-$ artifacts with steep lateral retouches; 4 - narrow-face bladelets core

The assemblage contains a number of unidirectional, volumetric blade cores in different stages of exploitation. The analysed subset $(\mathrm{n}=7)$ shows a median length of $66 \mathrm{~mm}$ ( $\mathrm{min} .59 \mathrm{~mm}$; max. $111 \mathrm{~mm})$, median width of $52 \mathrm{~mm}(\min .37 \mathrm{~mm}$; max. $67 \mathrm{~mm}$ ), median thickness of $44 \mathrm{~mm}$ (min. $30 \mathrm{~mm}$; max. $67 \mathrm{~mm}$ ) and striking angles at around $60^{\circ}$. Crested blades are present. Bidirectional blade production is indicated by a few blades with alternating negatives from opposite directions (e. g. Пясецький 2009, рис. 37: 12).

Bladelets are often obtained from characteristic cores-on-flake with a narrow reduction face (fig. 3: 4; 4: 1; Пясецький 2009, рис. 35: 3, 5, 7). The back of the cores is formed by a crest that transitions into a likewise crest-shaped distal end. The crest is used to control the lateral and distal morphology of the core. The negatives of the reduction face are often very regular. A sample of 15 narrowface cores has been recorded with a median length of $65 \mathrm{~mm}$ (min. $31 \mathrm{~mm}$; max. $82 \mathrm{~mm}$ ), median width of $25 \mathrm{~mm}$ (min. $14 \mathrm{~mm}$; max. $40 \mathrm{~mm}$ ), and median thickness of $41 \mathrm{~mm}$ (min. $25 \mathrm{~mm}$; max.

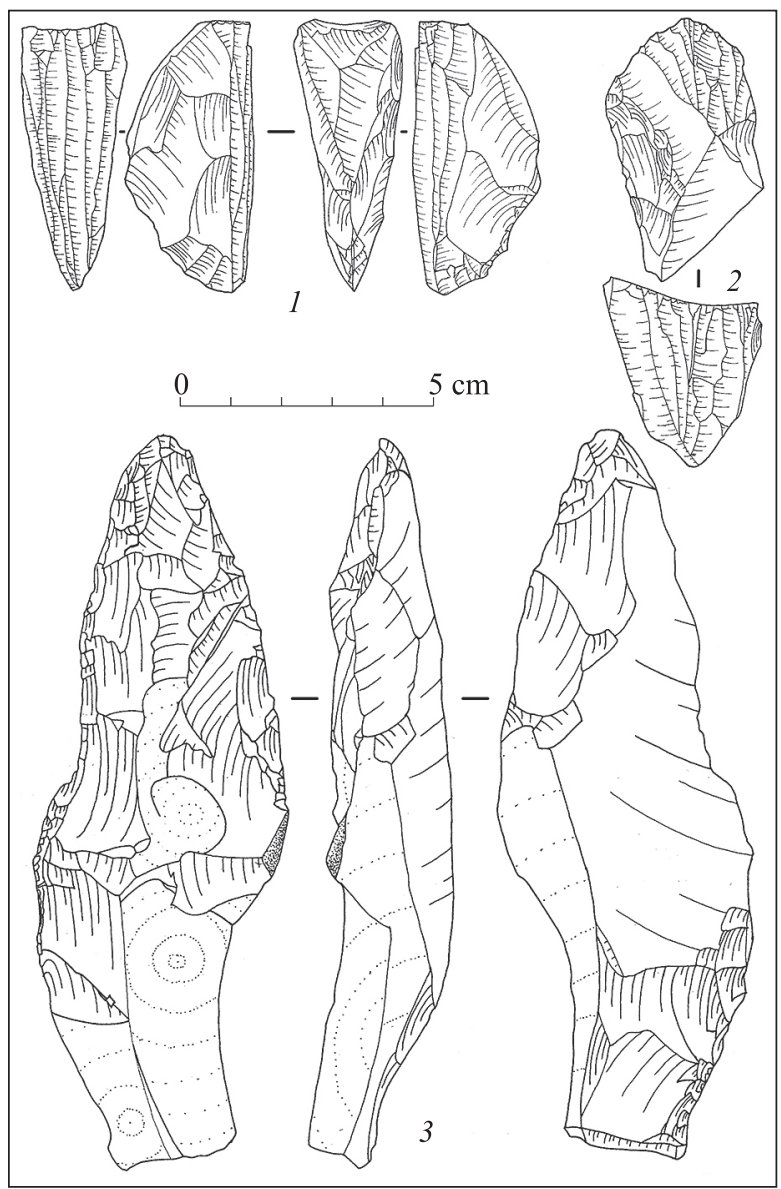

Fig. 4. Artifacts from V. K. Piasetskyi's surface collection and test trench at Myrohoshcha I. 1 - narrow-face bladelet core; 2 -carinated core; 3 - bifacially shaped artifact

$62 \mathrm{~mm}$ ). The striking angles are between $60^{\circ}$ and $85^{\circ}$. Additionally, bladelets are produced from the lateral edges of blanks without much further preparation (Пясецький 2009, рис. 13).

Short bladelets were obtained from carinated cores ( $n=6$; fig. 4: 2; Пясецький 2009, pис. 37: 1, $2)$. The distal part can be pointed or flat. The median length of the sampled specimens is $25 \mathrm{~mm}$ ( $\mathrm{min}$. $19 \mathrm{~mm}$; max. $37 \mathrm{~mm}$ ), the median width is $38 \mathrm{~mm}$ (min. $27 \mathrm{~mm}$; max. $55 \mathrm{~mm}$ ), and the median thickness is $55 \mathrm{~mm}$ (min. $45 \mathrm{~mm}$; $\max .62 \mathrm{~mm}$ ). The striking angles are at around $60^{\circ}$.

Additionally, flakes (and rarely blades) are produced from rather flat flake cores with a more or less radial pattern of centripetal flake removals (fig. 2: $1,2)$. These cores can be made on raw volumes as well as on larger flakes. The latter are exploited on one or both of their dorsal and ventral sides, sometimes leading to a Kombewa-like appearance. The sample of 5 flat flake cores has a median length of $65 \mathrm{~mm}$ (min. $55 \mathrm{~mm}$; max. $101 \mathrm{~mm}$ ), median width of $63 \mathrm{~mm}$ (min. $50 \mathrm{~mm}$; max. $80 \mathrm{~mm}$ ), and median thickness of $25 \mathrm{~mm}$ (min. $17 \mathrm{~mm}$; max. $38 \mathrm{~mm}$ ). 


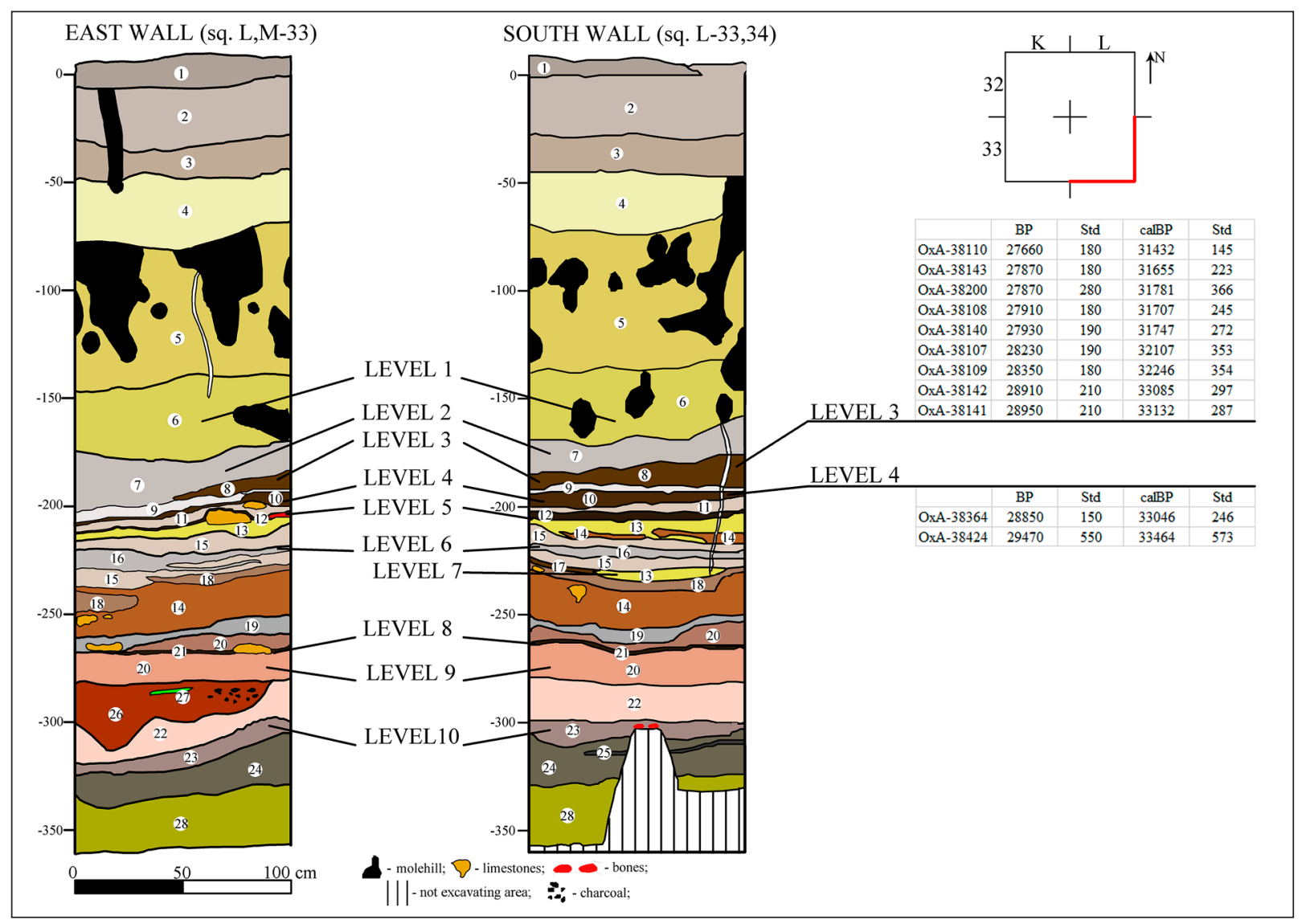

Fig. 5. Stratigraphic section with the origin of radiocarbon dates from the new excavation of Myrohoshcha I

The striking angles are with values at around $45^{\circ}$ often very acute. The flat flakes removed from these cores often have a faceted butt.

The tool spectrum comprises besides end-scrapers (Пясецький 2009, рис. 36: 1-9, 11, 12) and burins (Пясецький 2009, pис. 37: 9), a number of side-scrapers and flakes with intensive, steep lateral retouches (fig. 3: 2, 3). There are also blades with convergent lateral retouches, sometimes invasive at the tip (fig. 2: 4). These pieces are sometimes referred to as pointed blades, points a face plane, or Pavlov points. Additionally, there are large and thin flakes, most likely from flat flake cores, showing flat and invasive retouches or unifacial surface shaping (fig. $2: 3 ; 3: 1$ ). A large, thick, and irregular blade shows bifacial retouches (fig. 4: 3). A broken tip of a long borer as well as a laterally retouched pointed bladelet (Пясецький 2009, рис. 39: 9, 10) also deserve mentioning.

Myrohoshcha I: new excavations. The stratigraphy was studied in $4.0 \mathrm{~m}^{2}$ test pits. The $3.65 \mathrm{~m}$ deep stratigraphic sequence consists of 28 lithological layers (fig. 5). The Pleistocene sediments are represented by loess and silt deposits, within which ten archaeological levels were found. Level 1 accumulated in loess and contains only a few artifacts; level 2 accumulated in mixed deposits and contains
194 artifacts (fig. 6: 1). Levels 3-5 accumulated in silt deposits. The collection from level 3 is represented by 3810 artifacts (fig. 6: 2-9), 16 fragments of unidentifiable bones, and numerous small pieces of charcoal. The toolkit contains burins (fig. 6: 6, 7), end-scrapers (fig. 6: 9), a backed point on a microblade (fig. 6: 5), fragments of backed microblades and bladelets (fig. 6: 2-4), and retouched blades. There are 10 radiocarbon dates on charcoal available for level 3 , which place the occupation roughly around $32 \mathrm{kyr}$ cal BP (Table 1). The collection from level 4 is represented by 392 artifacts (fig. 6: 10-12) and 5 fragments of unidentifiable bones. The toolkit contains end-scrapers and retouched blades and flakes (fig. 6: 10,11). For level 4, two radiocarbon dates are available (Table 1), indicating a calendar age of roughly $33 \mathrm{kyr}$ cal BP. The collection from level 5 is represented by 169 artifacts, 7 fragments of unidentifiable bones, and 1 piece of burned bone. The toolkit contains retouched blades and flakes. Level 6 accumulated in silt deposits, the collection is represented by 639 artifacts, 16 fragments of unidentifiable bones, and numerous small pieces of charcoal. The toolkit contains end-scrapers and retouched flakes. The few finds of level 7 accumulated in sand. Level 8 accumulated in thin silt deposits. The collection is 


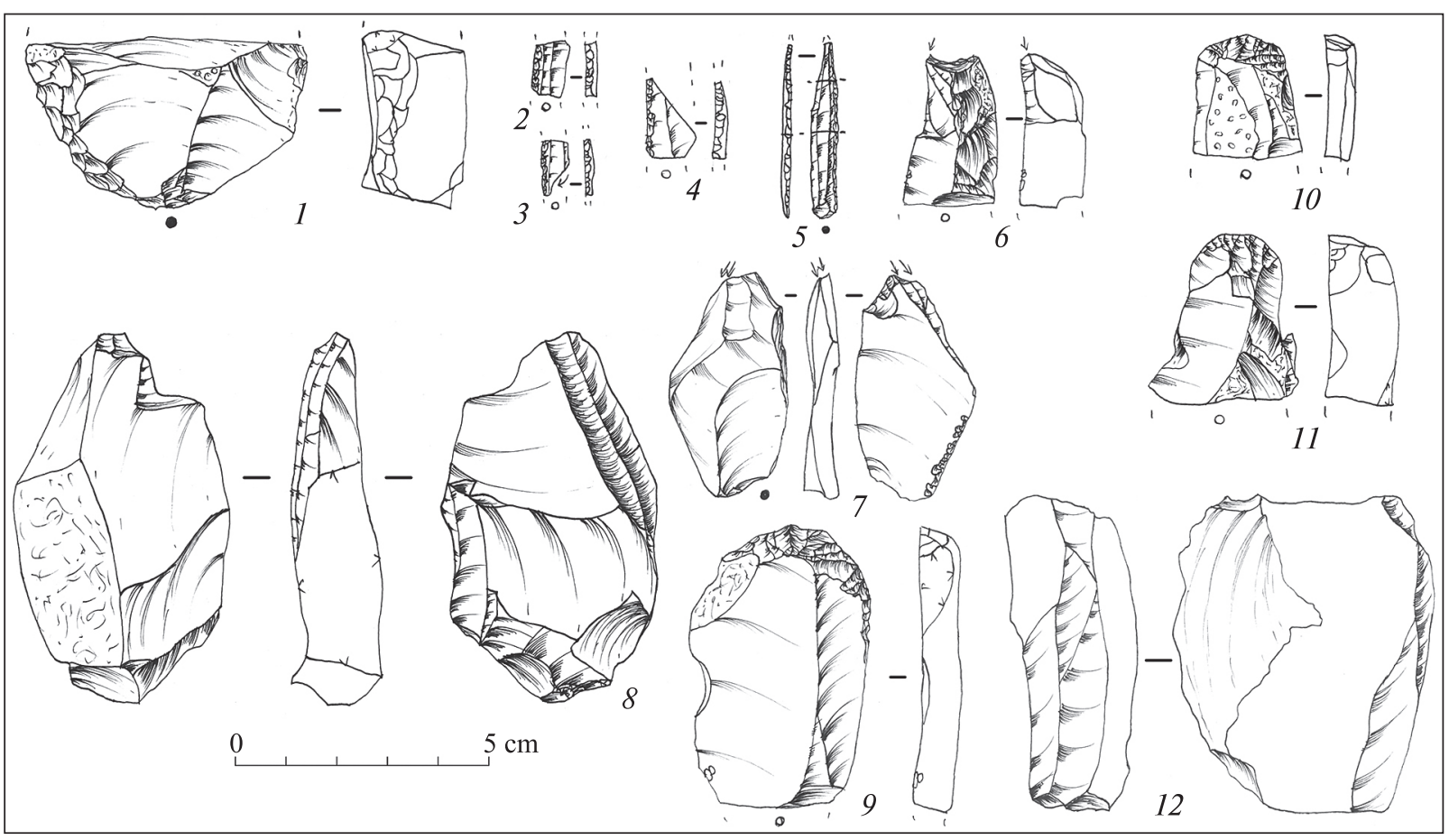

Fig. 6. Artifacts from the recent excavations at Myrohoshcha I. Flint artifacts from test-pit 2018: 1 - level 2, retouched flake fragment; 2-4 - level 3, fragment of backed microblade and bladelets; 5- level 3, backed point; 6-7- level 3, burins; 8- level 3, core; 9- level 3, end-scraper; 10-11-level 4, end-scrapers; 12 - level 4, core fragment

represented by 52 artifacts, 1 fragment of an unidentifiable bone, and numerous small pieces of charcoal. Level 9 accumulated in silt deposits, the collection is represented by 197 artifacts, 1 fragment of unidentifiable bone, and numerous small pieces of charcoal. The toolkit contains retouched blades and flakes. Level 10 accumulated in silt deposits, the collection is represented by 77 artifacts, 3 fragments of unidentifiable bones, and numerous small pieces of charcoal.

A set of 13 consistent radiocarbon dates from layers 3 and 4 (see Table 1) can be aggregated to two weighted averages and indicate a usage of the site roughly between 34 and $31 \mathrm{kyr}$ cal BP (fig. 7).

Hriadky, test trenches and excavations. The attribute analysis has been done for 56 artifacts (figs. 8-10). Unidirectional blade cores $(n=4)$ show a median length of $70 \mathrm{~mm}$ ( $\mathrm{min} .64 \mathrm{~mm}$; max. $90 \mathrm{~mm}$ ), median width of $56 \mathrm{~mm}$ (min. $48 \mathrm{~mm}$, max. $67 \mathrm{~mm}$ ), and a median thickness of $45 \mathrm{~mm}$ (min. $33 \mathrm{~mm}$; max. $57 \mathrm{~mm}$ ). The striking angles are around $75^{\circ}$ and crested blades are present. Core corrections from the distal end are often visible. The largest blade is $140 \mathrm{~mm}$ long (the distal part is not preserved) and shows evidence of bidirectional flaking (fig. 9: 1).

Narrow-face cores-on-flakes for bladelet production are present (fig. 10: 5). The recorded subsample $(\mathrm{n}=4)$ shows a median length of $81 \mathrm{~mm}$ (min. $70 \mathrm{~mm}$; max. $117 \mathrm{~mm}$ ), a median width of
$22 \mathrm{~mm}$ (min. $14 \mathrm{~mm}$; max. $58 \mathrm{~mm}$ ), and median thickness of $58 \mathrm{~mm}$ (min. $33 \mathrm{~mm}$; max. $89 \mathrm{~mm}$ ). Striking angles are at around $60^{\circ}$. One narrowface core is made on a fragment of a unifacially shaped tool, underlining the internal coherence of these two technological features. Less standardized bladelet production from the lateral edges of flakes and blades can also be observed.

Carinated bladelet cores $(\mathrm{n}=14$; fig. 9: 5; 10 : $3,4)$ show a median length of $17 \mathrm{~mm}(\mathrm{~min} .6 \mathrm{~mm}$; max. $28 \mathrm{~mm}$ ), a median width of $31 \mathrm{~mm}$ (min. $22 \mathrm{~mm}$; max. $82 \mathrm{~mm}$ ), and median thickness of $54 \mathrm{~mm}$ (min. $34 \mathrm{~mm}$; max. $38 \mathrm{~mm}$ ). The striking angles are usually between 45 and $60^{\circ}$, but $80^{\circ}$ is also attested. The distal end can be flat or pointed.

Flat flake cores ( $\mathrm{n}=3$; fig. $8: 3)$ are relatively similar in their dimension and show a median length of $68 \mathrm{~mm}$ (min. $68 \mathrm{~mm}$; max. $74 \mathrm{~mm}$ ), median width of $63 \mathrm{~mm}$ (min. $48 \mathrm{~mm}$; max. $68 \mathrm{~mm}$ ), and median thickness of $24 \mathrm{~mm}$ (min. $18 \mathrm{~mm}$; max. $43 \mathrm{~mm}$ ). The striking angles are rather acute. Flakes are often thin and large with characteristic patterns of negatives on the dorsal side and faceted striking platform remnants (fig. 10: 1, 2). There are also rather thick éclats débordants.

End-scrapers and burins are present (Пясецький 2009, рис. 44, 45), as are side-scrapers (also double) with invasive retouches (Пясецький 2009, рис. 47: 13, 14). Additionally, flakes and blades with intensive and steep lateral retouches occur (fig. 8: 1, 2). 
Unifacial surface shaping on large flakes and blades is attested (fig. 9: 4). Since many of these pieces are at display at the museum and could not be removed, a verification of the presence of bifacial pieces was not possible. Elongated fragments with convergent lateral retouches also occur (fig. 9: 2, 3; Пясецький 2009, рис. 47: 17). One fragment of a backed point on blade is present in the assemblage.

Zhorniv, excavation areas 1 and 2. Due to the proximity of the two excavation areas $(<100 \mathrm{~m})$ and the similar composition of the assemblage, they are evaluated jointly. Initially, V. K. Piasetskyi (2009) distinguished four layers at the excavation area 1 (point 4). However, a large flake core has been refitted from about 20 pieces by V. K. Piasetskyi. Since these pieces come from layers I and II, the material documented within these layers should be considered as belonging to a single occupation event. This notion is further corroborated by other refittings. The collection comprises also relatively

Table 1. Radiocarbon dates

\begin{tabular}{|c|c|c|c|c|c|c|c|c|c|c|c|c|c|c|}
\hline Site & $\mathbf{L}$ & $\mathbf{M}$ & Lab.-Nr. & BP & Std & $\%$ & calBP & Std & $\mathbf{P} \%$ & BP-w & Std-w & CalBP-w & Std-w & $\begin{array}{l}\text { Refe- } \\
\text { rences }\end{array}$ \\
\hline Zshorniv & IIa & $\mathrm{ch}$ & $\begin{array}{l}\text { GIN- } \\
4143\end{array}$ & 28100 & 500 & 1.8 & 32137 & 601 & & & & & \multirow{16}{*}{110} & $\begin{array}{l}\text { Piasetskyi } \\
2009\end{array}$ \\
\hline Myrohoshcha I & 3 & $\mathrm{ch}$ & $\begin{array}{l}\text { OxA- } \\
38110\end{array}$ & 27660 & 180 & 0.7 & 31432 & 145 & $*$ & & & & & This paper \\
\hline Myrohoshcha I & 3 & $\mathrm{ch}$ & $\begin{array}{l}\text { OxA- } \\
38143\end{array}$ & 27870 & 180 & 0.6 & 31655 & 223 & $*$ & & & & & This paper \\
\hline Myrohoshcha I & 3 & $\mathrm{ch}$ & $\begin{array}{l}\text { OxA- } \\
38200\end{array}$ & 27870 & 280 & 1.0 & 31781 & 366 & $*$ & & & & & This paper \\
\hline Myrohoshcha I & 3 & $\mathrm{ch}$ & $\begin{array}{c}\text { OxA- } \\
38108\end{array}$ & 27910 & 180 & 0.6 & 31707 & 245 & $*$ & & & & & This paper \\
\hline \multirow[t]{2}{*}{ Myrohoshcha I } & 3 & $\mathrm{ch}$ & $\begin{array}{l}\text { OxA- } \\
38140\end{array}$ & 27930 & 190 & 0.7 & 31747 & 272 & $*$ & & & & & This paper \\
\hline & & & & & & & & & 84.2 & 27843 & 87 & 31550 & & \\
\hline Myrohoshcha I & 3 & $\mathrm{ch}$ & $\begin{array}{l}\text { OxA- } \\
38107\end{array}$ & 28230 & 190 & 0.7 & 32107 & 353 & $*$ & & & & & This paper \\
\hline Myrohoshcha I & 3 & $\mathrm{ch}$ & $\begin{array}{l}\text { OxA- } \\
38109\end{array}$ & 28350 & 180 & 0.6 & 32246 & 354 & $*$ & & & & & This paper \\
\hline Myrohoshcha I & 3 & $\mathrm{ch}$ & $\begin{array}{l}\text { OxA- } \\
38363\end{array}$ & 28410 & 140 & 0.5 & 32322 & 319 & $*$ & & & & & This paper \\
\hline & & & & & & & & & 74.8 & 28348 & 96 & 32240 & & \\
\hline Myrohoshcha I & 4 & $\mathrm{ch}$ & $\begin{array}{l}\text { OxA- } \\
38364\end{array}$ & 28850 & 150 & 0.5 & 33046 & 246 & $*$ & & & & & This paper \\
\hline Myrohoshcha I & 3 & $\mathrm{ch}$ & $\begin{array}{l}\text { OxA- } \\
38142\end{array}$ & 28910 & 210 & 0.7 & 33085 & 297 & $*$ & & & & & This paper \\
\hline Myrohoshcha I & 3 & $\mathrm{ch}$ & $\begin{array}{l}\text { OxA- } \\
38141\end{array}$ & 28950 & 210 & 0.7 & 33132 & 287 & $*$ & & & & & This paper \\
\hline Myrohoshcha I & 4 & $\mathrm{ch}$ & $\begin{array}{l}\text { OxA- } \\
38424\end{array}$ & 29470 & 550 & 1.9 & 33464 & 573 & $*$ & & & & & This paper \\
\hline \multirow[t]{2}{*}{ Myrohoshcha I } & 3 & $\mathrm{ch}$ & $\begin{array}{l}\text { OxA-X- } \\
3004-19 \\
\end{array}$ & 29570 & 970 & 3.3 & 33425 & 1031 & $*$ & & & & & This paper \\
\hline & & & & & & & & & 79.3 & 28918 & 103 & 33136 & 196 & \\
\hline Stillfried B & & $\mathrm{ch}$ & $\begin{array}{l}\text { GrN- } \\
2523\end{array}$ & 28200 & 290 & 1.0 & 32119 & 438 & $*$ & & & & & $\begin{array}{l}\text { Buch \& } \\
\text { Zöller } \\
1990\end{array}$ \\
\hline Stillfried B & & $\mathrm{ch}$ & $\begin{array}{l}\text { GrN- } \\
2533\end{array}$ & 28340 & 220 & 0.8 & 32242 & 390 & $*$ & & & & & $\begin{array}{l}\text { Buch\& } \\
\text { Zöller } \\
1990\end{array}$ \\
\hline \multirow[t]{2}{*}{ Stillfried B } & & $\mathrm{ch}$ & $\begin{array}{l}\text { GrN- } \\
11188\end{array}$ & 28900 & 1400 & 4.8 & 32897 & 1319 & $*$ & & & & & $\begin{array}{l}\text { Buch \& } \\
\text { Zöller } \\
1990\end{array}$ \\
\hline & & & & & & & & & 84.6 & 28298 & 174 & 32182 & 344 & \\
\hline
\end{tabular}

L: layer; M: material; ch: charcoal; P \%: Probability of the weighted average (w) that above-listed dates marked with * are statistically identical 


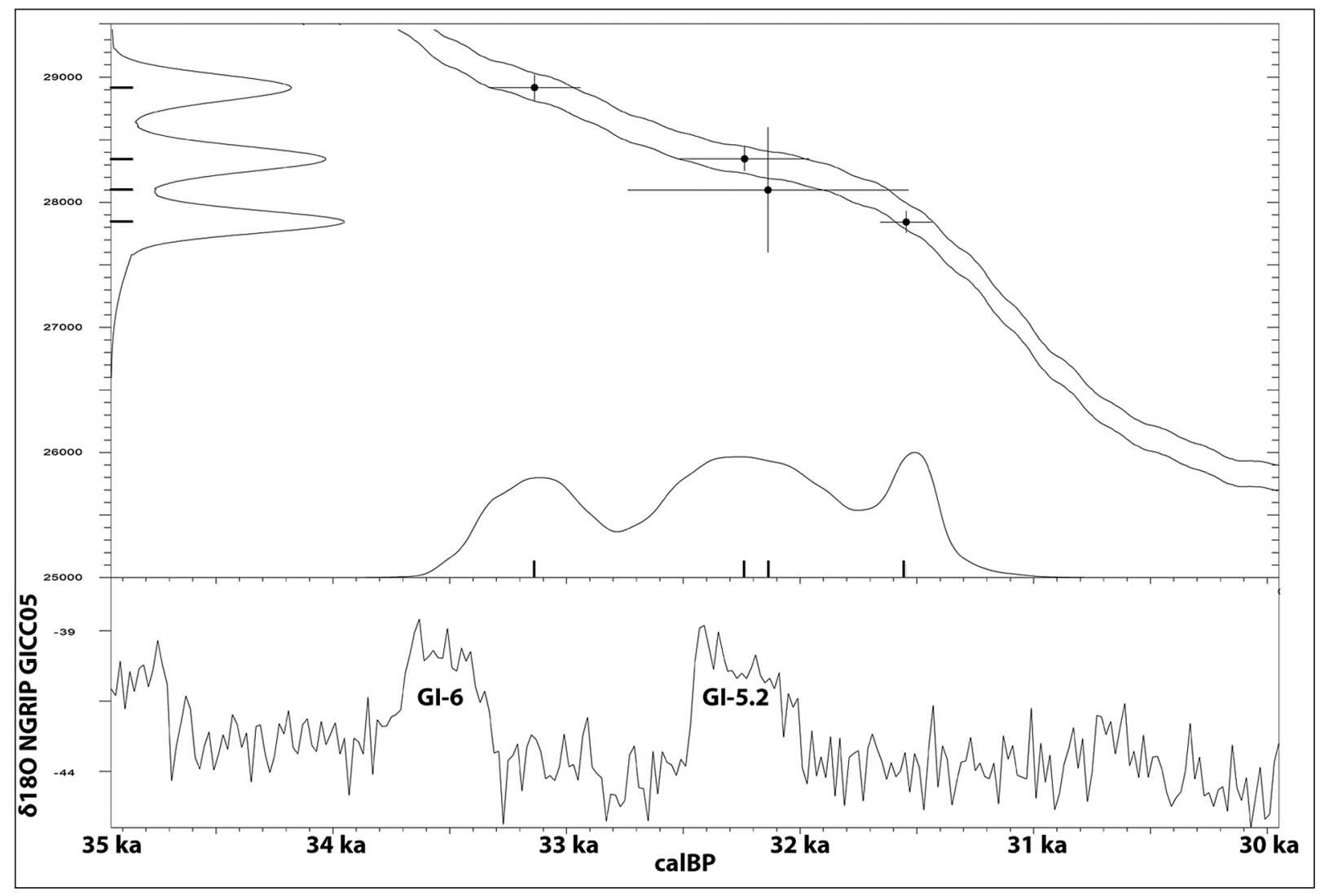

Fig. 7. Radiocarbon date from Zhorniv and weighted averages of the recent excavations at Myrohoshcha I (for details see Table 1). All dates calibrated with the IntCal13 curve (Reimer et al. 2013) as implemented in CalPal2014 (Weninger et al. 2014). Weighted averages calibrated with CalPal2014

small pieces. From Zhorniv, 86 pieces have been recorded for attribute analysis (fig. 11-13).

Blade production from volumetric cores is attested on-site and was carried out in a unidirectional fashion (Пясецький 2009, рис. 22: 5, 6, 9). Negatives from the distal part of the core, sometimes removing parts of the striking platform, seem to be the result of core corrections rather than of bidirectional blade production. However, some cores show a second striking platform at the distal part of the core. Here, the evidence indicates a unidirectional production from two platforms that have been used subsequently, in contrast to a true bidirectional flaking strategy. The three recorded specimens are between 73 and $85 \mathrm{~mm}$ long, 52 and $67 \mathrm{~mm}$ wide, and 24 and $61 \mathrm{~mm}$ thick. The flaking angles are around $55^{\circ}, 70^{\circ}$, and $85^{\circ}$. The longest blade, the distal part of which is not entirely preserved, measures ca. $125 \mathrm{~mm}$ in length (fig. 13: 1).

Bladelet production from narrow-face cores occurs. Beside flakes, flat plaquettes and frost sherds serve as blanks (fig. 13: 3). One core is made on a fragment of an end-scraper with invasive retouch. Here, the curved, retouched edge of the scraper is used as crested back and distal part. In one case, the initial reduction surface was subse- quently used as striking platform to obtain bladelets from the former back of the core. The median length of the 4 recorded cores is $70 \mathrm{~mm}$ (min. $52 \mathrm{~mm}$; max. $105 \mathrm{~mm}$ ), the median width is $26 \mathrm{~mm}$ (min. $17 \mathrm{~mm}$; max. $34 \mathrm{~mm}$ ), and median thickness is $53 \mathrm{~mm}$ (min. $40 \mathrm{~mm}$; max. $58 \mathrm{~mm}$ ).

Carinated cores are present (fig. 12: 4). The largest specimen on a thick cortical flake has a length of $45 \mathrm{~mm}$ and shows heavy exploitation that ended in numerous hinge fractures (fig. 13: 5).

Flat flake cores are frequent and flaking has been carried out on both, the ventral and dorsal side of these cores (fig. 12: 5, 6; Пясецький 2009 , рис. 10). Their sizes range from larger specimens $(160 \times 135 \times 60 \mathrm{~mm})$ to smaller ones $(52 \times$ $56 \times 15 \mathrm{~mm}$ ). The obtained products are usually round or pointed flakes with on- and off-axis orientation and faceted striking platform remnants (Пясецький 2009, рис. 11, 12). It seems, however, that elongated flakes or blades have also been produced (fig. 11: 3). Éclats débordants are also present.

Besides end-scrapers (fig. 12: 1) and burins, side-scrapers are numerous. The latter are often made on large and rather thin cortical flakes and show invasive retouches (fig. 11: 1, 2; Пясецький 


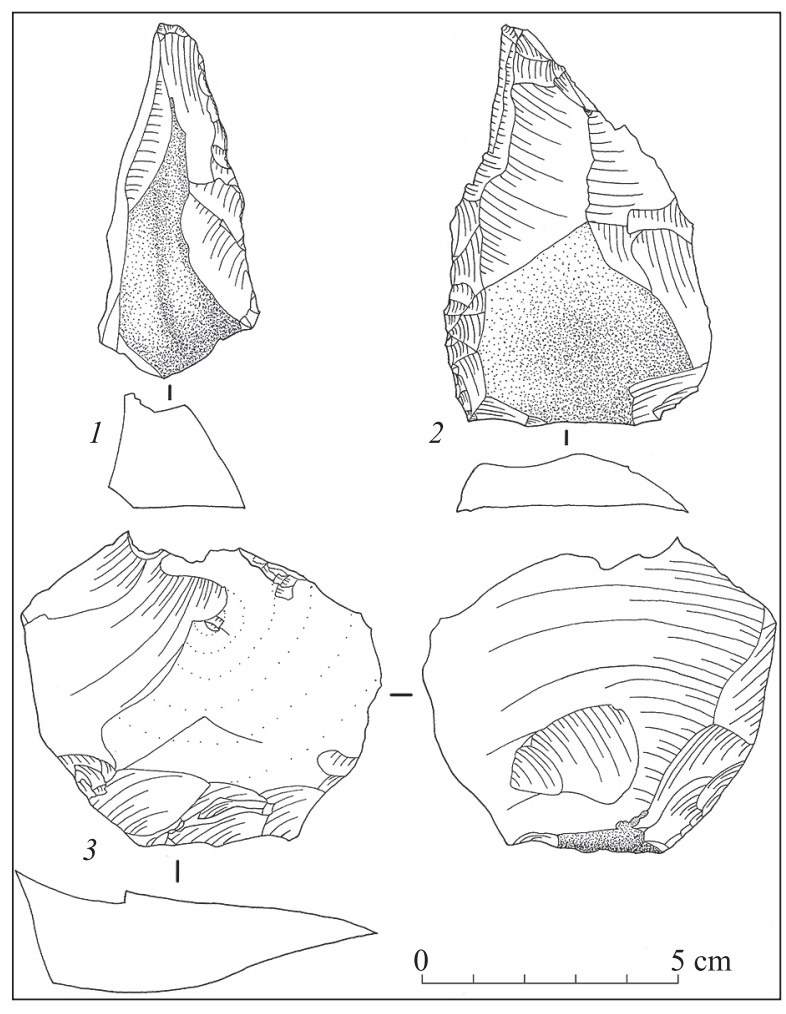

Fig. 8. Artifacts from V. K. Piasetskyi's test trenches and excavations at Hriadky. 1-2 - large cortical flakes with lateral retouch; 3 - flake core on frost sherd

2009, рис. 18-20). The 18 recorded specimens show a median length of $100 \mathrm{~mm}$ (min. $54 \mathrm{~mm}$; max. $154 \mathrm{~mm}$ ), median width of $62 \mathrm{~mm}$ (min. $43 \mathrm{~mm}$; max. $140 \mathrm{~mm}$ ), and median thickness of $15 \mathrm{~mm}$ (min. $10 \mathrm{~mm}$; max. $33 \mathrm{~mm}$ ). Additionally, uni- and bifacially shaped pieces occur (fig. 13: 4; Пясецький 2009, рис. 22: 1). Three fragments of laterally retouched points are reported. Special mentioning deserves a slender point with a lateral, backing retouch from excavation area 1.

Chervonyi Kamin, surface assemblage. For the attribute analysis, 96 artifacts have been recorded (fig. 14). Blade production from volumetric cores is attested (Пясецький 2009, рис. 27: 4-6). The two recoded specimens show dimensions of $99 \times 47 \times$ $37 \mathrm{~mm}$ and $66 \times 52 \times 32 \mathrm{~mm}$, respectively. Another six cores are small and rather directed towards the production of bladelets. They show a median length of $39 \mathrm{~mm}$ (min. $18 \mathrm{~mm}$; max. $48 \mathrm{~mm}$ ), median width of $31 \mathrm{~mm}$ (min. $25 \mathrm{~mm}$; max. $42 \mathrm{~mm}$ ), and median thickness of $40 \mathrm{~mm}$ (min. $20 \mathrm{~mm}$; max. $44 \mathrm{~mm})$. Two specimens $(87 \times 78 \times 51 \mathrm{~mm}$ and $50 \times 22 \times 31 \mathrm{~mm}$ ) show negatives of both blade and bladelets production. One of them shows two opposite striking platforms. However, the negatives extending from the second striking platform are all younger than those from the first and do not extend over the middle of the flaking surface, thus rather

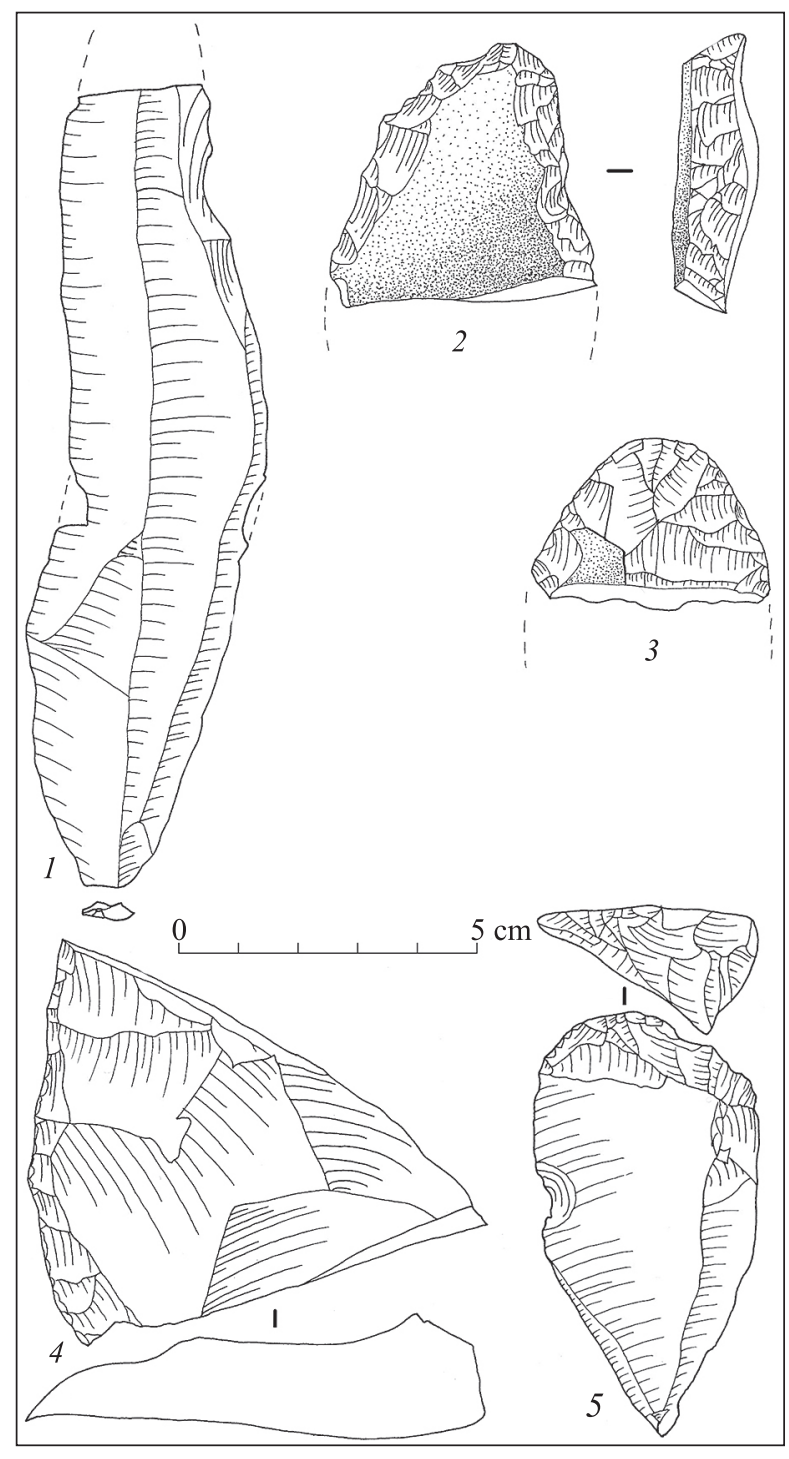

Fig. 9. Artifacts from V. K. Piasetskyi's test trenches and excavations at Hriadky: $1-$ blade; $2-3-$ artifacts with convergent retouches; 4 - fragment of a large flake with lateral and invasive retouches; 5 - carinated bladelet core

indicating core correction than blank production (Пясецький 2009, рис. 27: 7). Striking angles are at around $65^{\circ}$.

Narrow-face cores $(\mathrm{n}=8$; fig. 14: 2,3$)$ have a median length of $44 \mathrm{~mm}$ (min. $38 \mathrm{~mm}$; max. $104 \mathrm{~mm}$ ), median width of $18 \mathrm{~mm}$ (min. $7 \mathrm{~mm}$; max. $33 \mathrm{~mm}$ ), and median thickness of $32 \mathrm{~mm}$ (min. $22 \mathrm{~mm}$; max. $68 \mathrm{~mm}$ ).

Carinated cores are very abundant (fig. 14: 1, 7; Пясецький 2009, рис. 28: 1-15). The recorded 40 specimens show also shouldered specimens and pointed as well as flat distal parts. They have a median length of $25 \mathrm{~mm}$ (min. $11 \mathrm{~mm}$; max. $43 \mathrm{~mm}$ ), median width of $39 \mathrm{~mm}$ (min. $23 \mathrm{~mm}$; max. $71 \mathrm{~mm}$ ), a median thickness of $51 \mathrm{~mm}$ (min. $24 \mathrm{~mm}$; max. $80 \mathrm{~mm}$ ), and a median striking angle of $60^{\circ}\left(\min .45^{\circ} ; \max .80^{\circ}\right)$. For two pieces, 


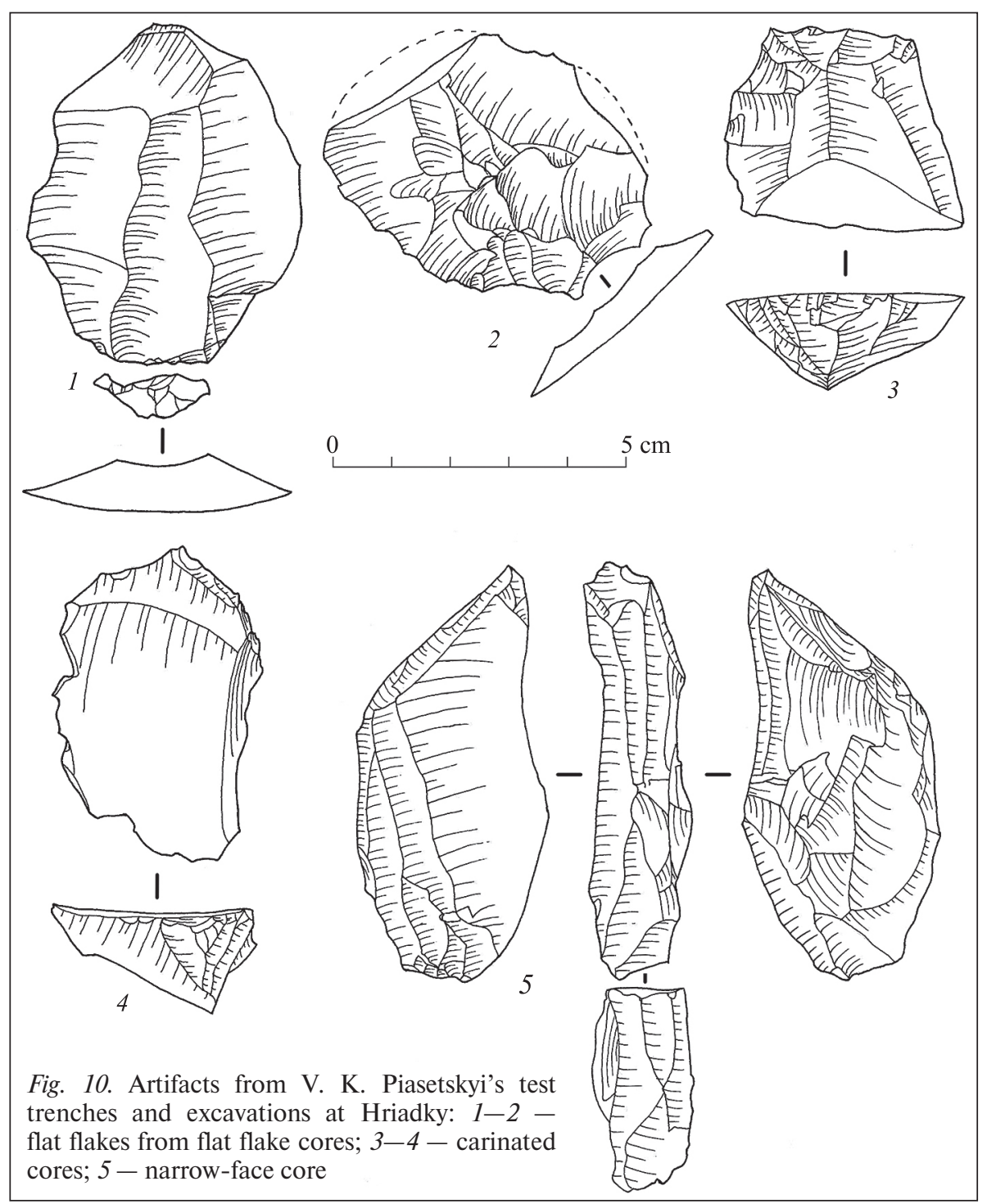

it seems that carinated cores with a formerly large flaking surface were turned $90^{\circ}$. The former lateral edges were trimmed by lateral negatives and used as reduction face, giving the core a nosed or shouldered shape.

Eight flat flake cores on flakes are present (Пясецький 2009, рис. 27: 8, 9). The three recorded specimens $(72 \times 70 \times 38 \mathrm{~mm}, 68 \times 61 \times$ $38 \mathrm{~mm}, 59 \times 51 \times 37 \mathrm{~mm}$ ) show an exploitation of both their dorsal and ventral sides.

The tool ensemble comprises end-scrapers and burins (Пясецький 2009, рис. 29) as well as pieces with steep and intensive lateral retouches (Пясецький 2009, рис. 30: 10). Evidences for invasive retouches and unifacial surface shaping are rare, but not absent. Additionally, three distal fragments of pointed blades occur (fig. 14: 4-6). The lack of small pieces is probably due to the fact that the collection was obtained by surface material alone. Flakes, however, are also under-represented. This is because they were usually not re- covered (see: Пясецький 2009, с. 94, табл. 1, point 5).

\section{Discussion}

4.1 Recurrent joint occurrence of characteristic traits. The technological and typological analysis of the inventories from Myrohoshcha I, Hriadky, Zhorniv, and Chervonyi Kamin shows the recurrent joint occurrence of eight specific traits, namely (1) blade production from uni- and (to a lesser extent) bidirectional volumetric cores, (2) blank production from flat flake cores, (3) bladelet production from carinated cores on flakes (sometimes also shouldered), (4) bladelet production from narrowface cores on flakes with a crested back, (5) intensive steep retouches on medium-sized cortical blanks, (6) invasive flat lateral retouch on large, often cortical flakes, (7) pointed blades (or Pavlov points, or points a face plane), and (8) uni- or bifacial surface shaping. Long borers occasionally occur. Additionally, there 


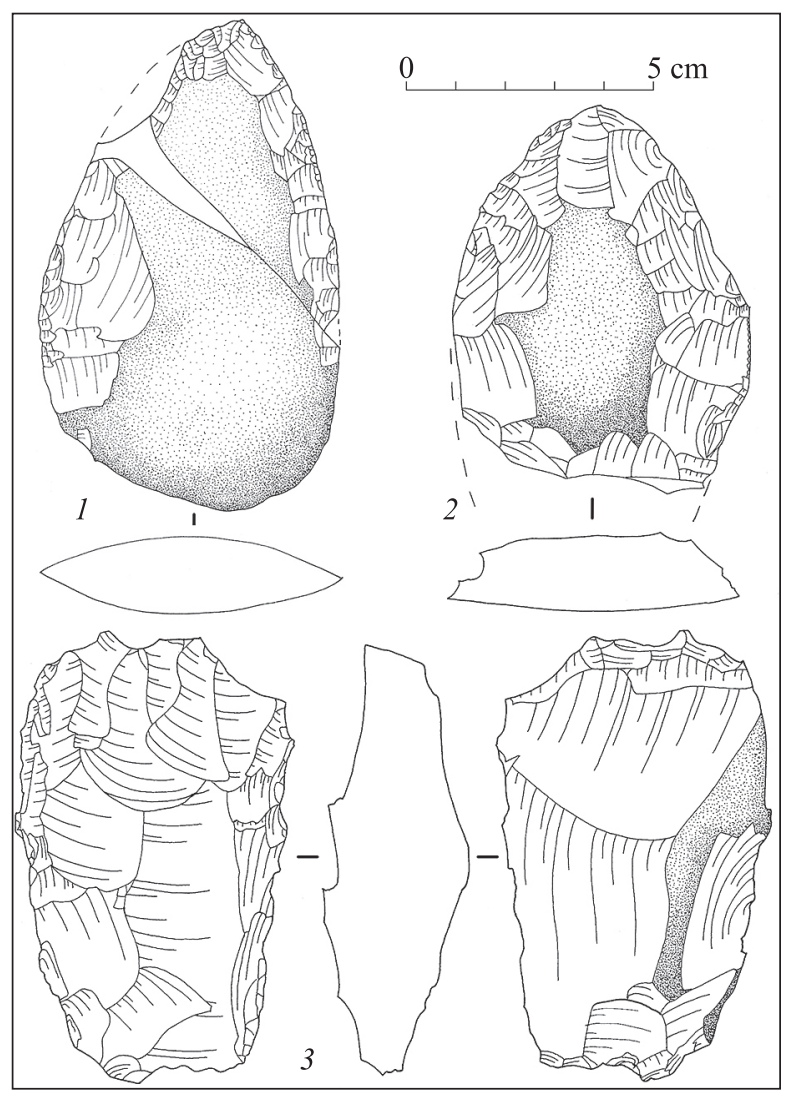

Fig. 11. Artifacts from V. K. Piasetskyi's excavations at Zhorniv: $1-2-$ large cortical flakes with lateral and invasive retouch; 3 - core-on-flake

are burins, end-scrapers, splintered pieces, and laterally retouched as well as notched pieces. The microlithic component in the assemblages is low and retouched or unretouched micro-bladelets (the products of carinated cores and small narrow-face cores) are lacking completely. This is probably due to two reasons. First, some assemblages are surface collections. Second, the rather coarse excavation techniques and a lack of wet-sieving are probably also responsible for this bias. However, backed and pointed blades and bladelets are documented in a few cases, for instance from Zhorniv. The new excavations at Myrohoshcha I, where sediments have been sieved regularly, yielded 4 microlithic pieces $4.0 \mathrm{~m}^{2}$.

Considered individually, none of these traits is a sufficient condition for the attribution to a specific chronological or chorological unit. Nevertheless, it can be stated that these traits together form a consistent and regularly co-occurring set of typological and technological characteristics. However, given the wide range and comparably large number of technological methods applied, it cannot be expected that all traits are always represented in all assemblages.

The ratios of these traits in comparison to one another may thus vary.

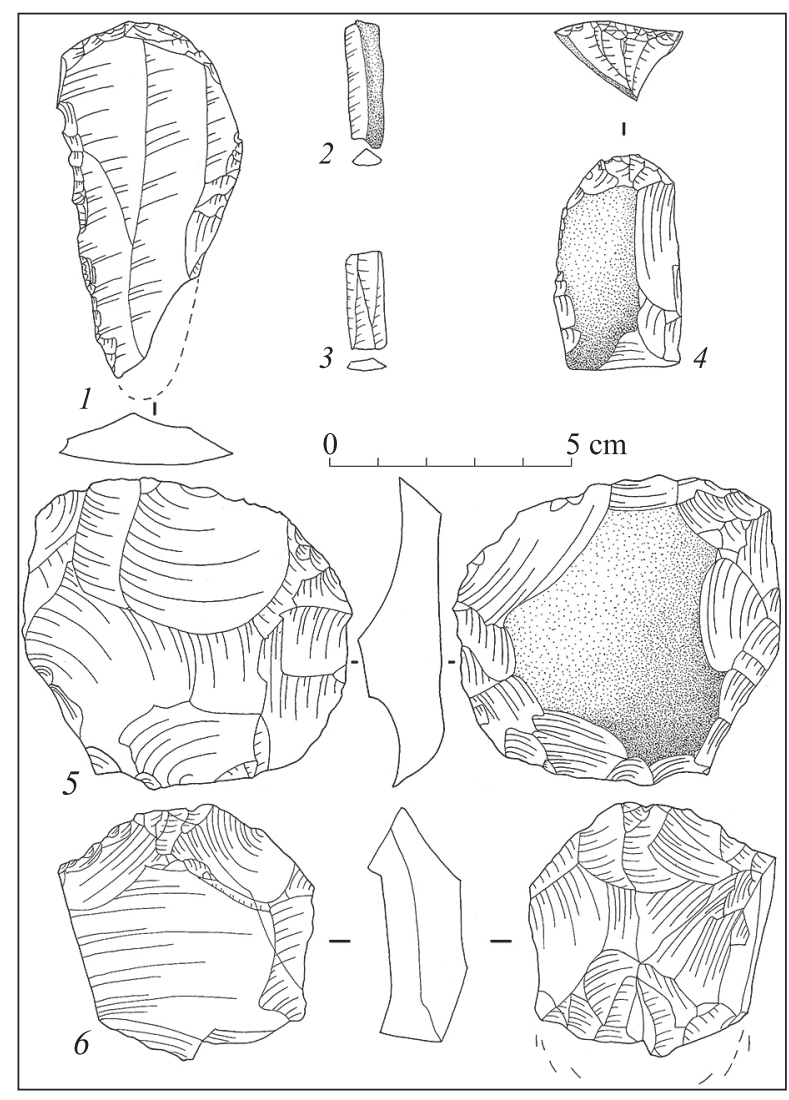

Fig. 12. Artifacts from V. K. Piasetskyi's excavations at Zhorniv: 1, 5 - end-scrapers; $2-3$ - bladelets; 4 carinated core; $6-7-$ flat flake cores

(1) Blade production from uni- and bidirectional volumetric cores

All assemblages show the production of often long and regular blades from volumetric cores. Primary and secondary crested blades are abundant. Blade production usually takes place in a unidirectional fashion. The cores often show a second striking platform opposed to the first one which serves for core correction to remove hinge fractures. Sometimes the cores are turned $180^{\circ}$ and a second sequence of unidirectional blade production is carried out, subsequent to the first. True bidirectional production with the alternating exploitation of one flaking surface from two opposed striking platforms is also attested, but not very frequent.

(2) Flake and blade production from flat flake cores

An important characteristic of all analysed assemblages is the presence of flat flake cores, showing a standardized exploitation. The cores themselves are rarely made on natural raw volumes. Most specimens are cores-on-flakes. The cortical blanks for the cores were produced from larger blocks of raw material under the exploitation of naturally suited angles. Sometime also frost sherds were selected. Two variants of subsequent blank production can 
be observed. In variant $\mathrm{A}$, the ventral side was used as striking platform, which sometimes shows traces of preparation, but usually was used without further modification. The products of variant A are large and comparably thin flakes with a slightly curved profile, a comparatively small striking platform remnant, and very acute flaking angle between about $60^{\circ}$ and $45^{\circ}$. Variant B uses the natural convexities of the ventral side for blank production. Here, the dorsal side of the flake is used as striking platform, which is usually prepared with some negatives prior to blank production. If this preparation is carried out all round, the remnants of cortex are usually still found in the centre of the dorsal side. After the preparation of the dorsal side, flakes (and rarely blades) are obtained from the ventral side in unidirectional, bidirectional, or centripetal fashion, often without any further preparation. Flakes early in the production sequence thus morphologically correspond to Kombewa-flakes. Flakes from later exploitation stages are usually non-cortical, flat and thin. They have an acute flaking angle and can show a uni- or bidirectional as well as centripetal scar pattern and both an on- and off-axis striking direction. The butts are often faceted and can also have a 'chapeau-degendarme' morphology. During core maintenance, éclats débordants are also produced.

It is particularly because of these cores and flakes why there has been the idea of a Mousterian component in the assemblages. However, it has to be stressed that the chaîne opératoire is distinctively different from Mousterian-Levallois cores (Boëda 1994) and that the observable similarities are only superficial. Beside the fact that the cores in question are made on flakes, it is above all the use of the naturally convexities of the ventral side as opposed to prepared convexities which sets these both ways of production apart.

\section{(3) Bladelet production from carinated cores}

The second variant of cores on flakes is represented by carinated cores. Here, thick blanks were selected and the ventral face was used as a striking platform, while the distal part of the dorsal side served as flaking surface. The distal part of the core (i.e. the dorsal ridge of the initial blank) is left unaltered and delimits the length of the bladelets and determines their distal form (pointed or blunt). The distal convexities are thus determined by the shape of the piece which can be pointed (left-skewed, central/symmetrical, rightskewed), round, or flat. The organization of the lateral convexities is carried out from the striking platform. Usually, large negatives are stricken on the lateral side of the core for lateral trimming. Sometimes negatives directly adjacent to the flaking surface further reduced the width of the flaking face, giving the pieces

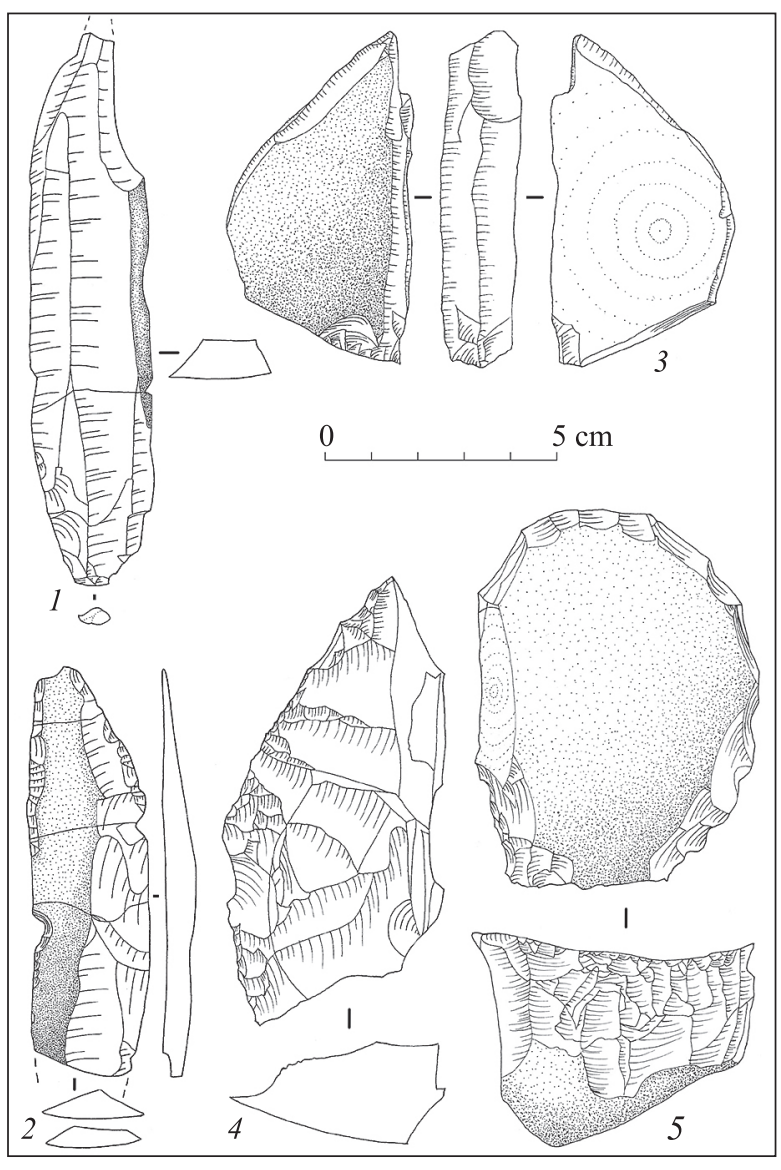

Fig. 13. Artifacts from V. K. Piasetskyi's excavations at Zhorniv: 1 - blade; 2 - blade with convergent lateral retouches; 3 - narrow-face core on a frost sherd; $4-$ large flake with lateral and invasive retouch; 5 - large bladelet core on cortical flake

the form of nosed or shouldered carinated cores. The back of the core has no function and is often blunt, but can also have other shapes.

\section{(4) Bladelet production from narrow-face cores}

The third variant of cores from flakes is represented by narrow-face cores. In contrast to carinated cores, where the blank is turned $180^{\circ}$, the blank is turned $90^{\circ}$ and the terminal or lateral edge of the blank is exploited as flaking surface. The striking platform is usually formed by one or more negatives stricken from the direction of the future flaking surface. The back and distal part of the core are formed by a single, continuous crest that allows the organization of the lateral and distal convexities. Despite of sometimes extensive reworking, ventral and dorsal sides are often still decipherable. Sometimes, the cores are turned and striking and flaking face switch their function.

\section{(5) Steeply and intensively retouched cortical} blanks

A characteristic component is also usually medium-sized cortical blanks with steeply and intensively retouched lateral edges. 


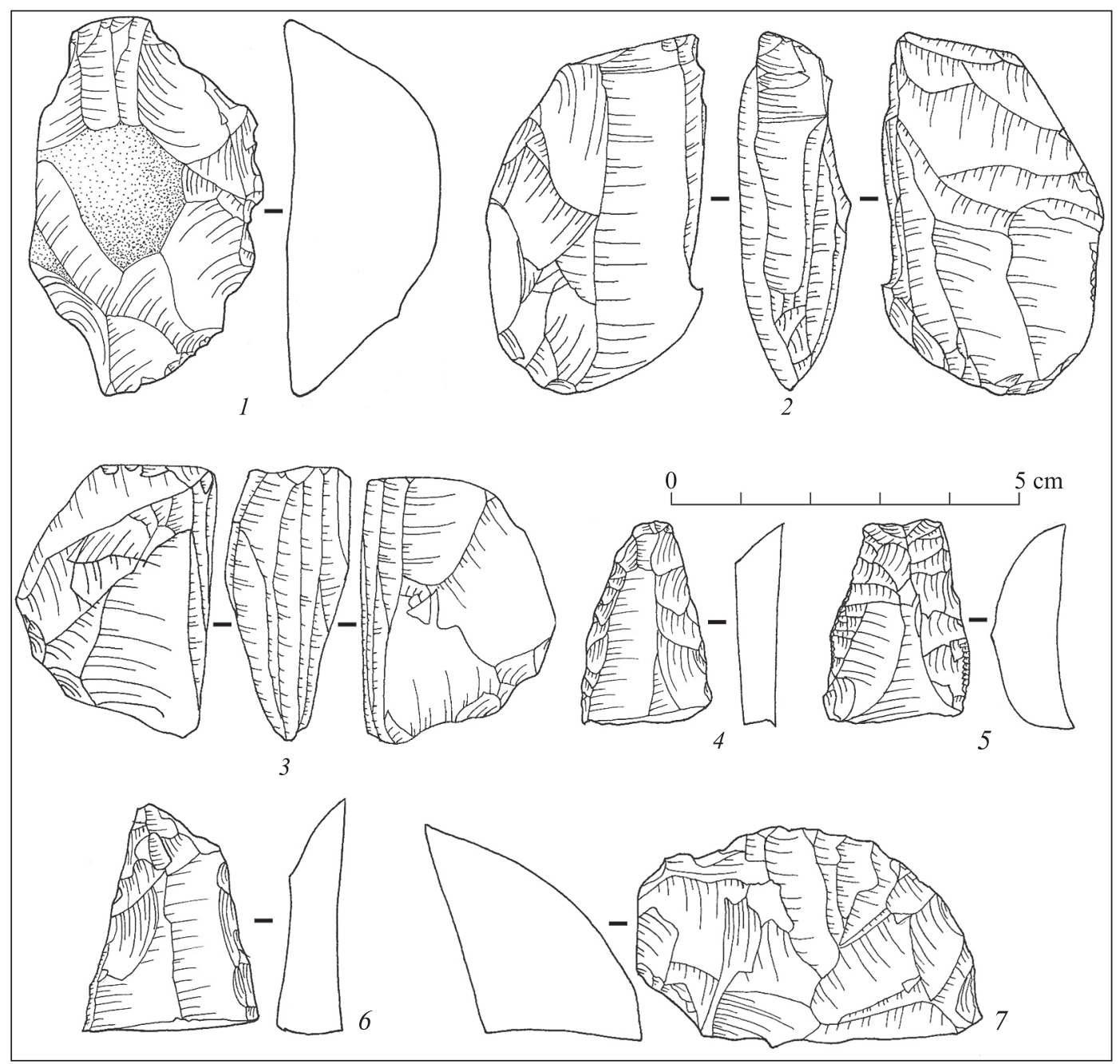

Fig. 14. Artifacts from the surface collection of Chervonyi Kamin: 1, 7- carinated cores; 2-3 - narrowface cores; 4-6- fragments of blades with convergent lateral retouches

\section{(6) Large cortical flakes with invasive retouch}

A conspicuous feature of the analysed assemblages is the presence of large and thin cortical flakes with flat extensive retouches. These flakes often show a comparatively small striking platform remnant with an acute angle and are obtained from larger cortical flakes, where the ventral side has served as striking platform (see point 2). The transition to unifacially shaped pieces is fluent.

\section{(7) Pointed blades}

Likewise characteristic are pointed blades, sometimes referred to as Pavlov points or points $a$ face plane. These tools often show invasive retouches or unifacial surface shaping, particularly in their pointed section. Sometimes, one side of the point shows a more acute angle than the other.

(8) Uni- and bifacially shaped pieces

Uni- and (less numerous) bifacial surface shaping of comparatively large and thick flakes is another characteristic of the assemblages in question. In both cases, the cortex has been removed largely or completely by flat, invasive retouches. Although being found mostly fragmented, the shape of these pieces varies between short and large to elongated and slender-pointed ovates. Smaller fragments of these tools are sometimes used as (narrow-face or wedge-shaped) cores for bladelet production.

It is quite possible that other, smaller assemblages from the region are also part of this group of sites. This applies, for instance, probably for Maidan-Plateau, located in close vicinity to Chervonyi Kamin. The small surface collection contains, despite the low number of finds, an interesting combination of characteristics, such as a volumetric blade core, a carinated and a narrow-face core, as well as a fragment of a large cortical flake with invasive retouch (Пясецький 2009, рис. 31). It is also possible that Ivanychi belongs to the same type of assemblage. Found by V. K. Piasetskyi (2009, c. 8788) at the north-western wall of limestone quarry, the lithological sequence of Ivanychi starts with the modern soil (thickness up to $0.3 \mathrm{~m}$ ), followed by 
loess (from 0.6 up to $3.0 \mathrm{~m}$ ), a «terra rossa» (about $0.4 \mathrm{~m})$, and limestone. The artifacts $(\mathrm{n}=306)$ were found on the contact of loess sediments and «terra rossa». Due to their position embedded in a stratigraphic sequence, the integrity of the assemblage is likely. A number of carinated cores occur together with a piece showing intensive lateral retouches (Пясецький 2009, рис. 25). However, the assemblage is small and these artifacts also occur in other periods. Their argumentative capacity is therefore limited. At Lypa I, a single archaeological level has been excavated on an area of more than $100 \mathrm{~m}^{2}$. A circular structure $(3.60 \times 3.75 \times 0.43 \mathrm{~m})$ with a fireplace has been described. Finds include faunal remains, wood charcoal, ochre and abundant flint artifacts (Савич 1975, с. 36-51). The artifact assemblage $(n=4970)$ contains volumetric blade cores alongside flat flake cores, carinated cores, and narrow-face cores. Large cortical flakes with steep retouches are also present. One fragment (Савич 1975, рис. 12, 19) attests the presence of unifacial shaping or at least larger flakes with invasive retouches. Fragments of backed bladelets and a long borer tip complement the assemblage's composition. The lithic tools are mainly made on large blades and comprise numerous dihedral and dihedral angle burins, pointed blades, and backed microliths (Савич 1975).

A first indication as to the age of these assemblages comes from the observation by V. K. Piasetskyi, who states that at Hriadky and Zhorniv, the finds were embedded in a paleosol which he correlates with the paleosol of Stillfried В (Пясецький 2009 , c. $31-33,39-48,116-124)$. The chronological position of Stillfried B is still debated (Sprafke 2015, 154 p.). However, there is a consistent set of three radiocarbon dates (see Table 1). Their weighted average of $32,182 \pm 344 \mathrm{cal} \mathrm{BP}$ is roughly in accord with a TL date of $29,800 \pm$ 2,500 years BP (QTL83C; Juvigné and Wintle 1988). With all necessary caution about these datings and the correlation of the soils, these observations may be taken as a weak hint that the artifacts are not younger than Greenland Interstadial 5.

From Zhorniv, excavation area 1, a larger concentration of charcoal fragments is reported. A dated sample resulted in a measurement of $28,100 \pm$ $500 \mathrm{BP}$ (GIN-4143), corresponding to a calendar age between 33 and $32 \mathrm{kyr}$ cal BP. Together with the dates recently obtained from Myrohoshcha I (see Table 1 and fig. 7), it can be stated that these assemblages were produced roughly between 34 to 31 kyr cal BP.

With regard to the proposed cultural succession, it can be stated that there are no Mousterian components in the assemblages under study. Early Aurignacian assemblages are likewise not attested. It appears futile to debate whether the analysed assemblages should be attributed to a late Aurignacian or an early Gravettian, since there seems to be a continuous development between these two archaeological units.

\section{Conclusion}

The sites of Myrohoshcha I, Hriadky, Zhorniv and Chervonyi Kamin present the same consistent set of typological and technological traits. Similar traits are observable also at Maidan-Plateau, Ivanychi and Lypa I. There is thus no convincing evidence of a long occupation history of the Volhynian region spanning from the Mousterian to the Late Upper Paleolithic, as stated previously. More likely and in accord with the available radiocarbon dates, is an occupation roughly between 35 and $30 \mathrm{kyr}$ cal BP.

\section{Acknowledgements}

We express our gratitude to L. A. Babinchuk, O. T. Kruk, O. P. Voituk, and A. A. Marchuk for the welcoming reception and their most appreciated help at the Rivne Regional Museum. Thanks also to O. Kaiser (Friederich-Aleander-Universität Erlangen-Nürnbegr, R. John, and L. HermsdorfKnauth (both from the Univesity of Cologne) for their help in the preparation of the figures.

This research was funded by the Deutsche Forschungsgemeinschaft, project «Between East and West. Social Networks and Environmental Conditions before, during and after the Last Glacial Maximum in Volhynia (Western Ukraine)».

Григорьев, Г. П. 1968. Начало верхнего палеолита и происхождение Ното sapiens. Ленинград: Наука.

Григорьев, Г. П. 1970. Верхний палеолит. Каменный век на территории СССР. Материалы и исследования по археологии СССР, 166, с. 43-63.

Нужний, Д. Ю. 2015. Верхній палеоліт західної і північної України (техніко-типологічна варіабельність та періодизація). Київ: видавець Олег Філюк.

Островский, М. И., Григорьев, Г. П. 1966. Липская палеолитическая культура. Советская археология, 4, c. 3-13.

Пясецький, В. К. 1999. Палеоліт східної частини Волинської височини. Vita Antiqua, 2, с. 8-17.

Пясецкий, В. К. 1999. Позднепалеолитическая стоянка Мирогоща I (Поле Вотрубы). Российская археология, 3, с. 98-107.

Пясецький, В. К. 2009. Палеоліт Волинської височини і Малого Полісся. Рівне: ТОВ «Друк Волині».

Рудинський, М. Я. 1952. Дубно-Кременецька палеолітична експедиція. Археологічні пам'ятки УРСР, IV, c. 143-154. 
Савич, В. П. 1975. Пізньопалеолітичне населення південнозахідної Волині. Київ: Наукова думка.

Ситник, О. С. 2010. Липська пізньопалеолітична культура: аналіз та інтерпретація джерел. Кам'яна доба України, 13, с.113-137.

Boëda, E. 1994. Le Concept Levallois: Variabilité des Méthodes. Paris: CNRS Editions.

Buch, M. W., Zöller, L. 1990. Gliederung und Thermolumineszenz-ChronologiederWürmlösse im Raum Regensburg. Eiszeitalter und Gegenwart, 40, s. 63-84.

Juvigné, E. H. \& Wintle, A. G. 1988. A New Chronostratigraphy of the Late Weichselian Loess Units in Middle Europe based on Thermoluminescence Dating. Eiszeitalter und Gegenwart, 38, p. 94-105.

Reimer, P. J., Bard, E., Bayliss, A., Beck, J.W., Blackwell, P. G., Bronk Ramsey, C., Buck, C. E., Cheng, H.,
Edwards, R. L., Friedrich, M., Grootes, P. M., Guilderson, T. P., Haflidason, H., Hajdas, I., Hatté, C., Heaton, T. J., Hoffmann, D. L., Hogg, A. G., Hughen, K. A., Kaiser, K. F., Kromer, B., Manning, S. W., Niu, M., Reimer, R. W., Richards, D. A., Scott, E. M., Southon, J. R., Staff, R. A., Turney, C. S. M, \& van der Plicht, J. 2013. IntCal 13 and Marine 13 radiocarbon age calibration curves 0-50,000 years cal BP. Radiocarbon, 55, p. $1869-1887$.

Sprafke, T. 2015. Löss in Niederösterreich. Archiv quartärer Klima- und Landschaftsveränderungen. Würzburg: Würzburg University Press.

Weninger, B., Jöris, O. \& Danzeglocke, U. 2014. CalPal2014. Cologne Radiocarbon Calibration \& Palaeoclimate Research Package, http://www.calpal.de, (access 09 November 2016).

Received 21.07.2020

\author{
А. Майєр ${ }^{1}$, Д. Ступак ${ }^{2}$, П. Васильєв ${ }^{3}$, I. Хоптинець ${ }^{4}$, В. Ткач \\ ${ }^{1}$ Ph.D., молодший професор, Інститут доісторичної археології, Кельнський університет, Німеччина, \\ ORCID 0000-0002-5021-3341, a.maier@uni-koeln.de \\ ${ }^{2}$ Кандидат історичних наук, науковий співробітник відділу археології кам'яної доби, \\ Iнститут археології НАН України, ORCID 0000-0002-0809-2179, stupak17@ukr.net \\ ${ }^{3}$ Молодший науковий співробітник відділу «Археологічний музей», Інститут археології НАН України, \\ ORCID 0000-0002-9800-8152, pavlikmorozovski@gmail.com \\ ${ }^{4}$ Старший науковий співробітник сектору археології та пам'яткознавства Держсавного наукового иентру захисту \\ культурної спадщини від техногенних катастроф, ORCID 0000-0003-1143-785X, vanhopta@ukr.net \\ ${ }^{5}$ Співробітник Волинської палеолітичної експедиції, Дубно, Україна, ORCID 0000-0002-5581-3784, duben@ukr.net
}

\section{ПРО ТЕХНОЛОГІЧНУ ТА ТИПОЛОГІЧНУ ЦІЛІСНІСТЬ КОМПЛЕКСІВ ПІВНІЧНО-ЗАХІДНОЇ УКРАЇНИ МІЖ 35 ТА 30 ТИС. КАЛ. РОКІВ ТОМУ}

Стоянки Мирогоща I, Грядки, Жорнів та Червоний Камінь розташовані в центральній частині Волинського лесового плато на північному заході України. Крем'яні комплекси стоянок походять як із розкопок, так і з поверхневих зборів. Ці матеріали мають низку характеристик, які традиційно трактуються, як типові для матеріалів різних хронологічних періодів. Тому вважалося, що ці колекції представляють палімпсести середнього та верхнього палеоліту. У 2018 і 2019 рр. було отримано нові матеріали під час польових досліджень стоянки Мирогоща I, а також оброблено колекцію Мирогощі I та крем’яні комплекси низки інших пам'яток, які зберігаються в Рівненському обласному краєзнавчому музеї.

В результаті проведених досліджень можемо стверджувати, що крем'яні комплекси стоянок Мирогоща I, Грядки, Жорнів та Червоний Камінь не є змішаними та не демонструють поступовий розвиток індустрій на цій території від середнього до верхнього палеоліту. Матеріали цих пам’яток демонструють однаковий послідовний набір типологічних та технологічних рис. Подібні ознаки спостерігаються також у крем'яних колекціях пам'яток Майдан-плато, Іваничі та Липа I. Найбільш вірогідно, ці типологічні та технологічні риси представляють цілісний набір особливостей, характерних для періоду приблизно від 35 до 30 тис. кал. р. т.

Проведені дослідження, виконані у межах міжнародного українсько-німецького археологічного проекту «Between East and West. Social networks and environmental conditions before, during and after Last Glacial Maximum in Volhynia, Western Ukraine», коштами фонду наукових досліджень Німеччини (Deutsche Forschungsgemeinschaft), грант DFG-392605832.

Ключ о в і сло в а: односторонні та двосторонні знаряддя, радіальні нуклеуси, торцеві нуклеуси, нуклеуси для пластин, вістря на пластинах.

\footnotetext{
А. Майер ${ }^{1}$, Д. Ступак², П. Васильев ${ }^{3}$, И. Хоптынеи ${ }^{4}$, В. Ткач ${ }^{5}$

${ }^{1}$ Ph.D., младший профессор, Институт доисторической археологии, Кельнский университет, Германия, ORCID 0000-0002-5021-3341, a.maier@uni-koeln.de

${ }^{2}$ Кандидат исторических наук, научный сотрудник отдела археологии каменного века, Институт археологии НАН Украины, ORCID 0000-0002-0809-2179, stupak17@ukr.net

${ }^{3}$ Младший научный сотрудник отдела «Археологический музей», Институт археологии НАН Украины, ORCID 0000-0002-9800-8152, pavlikmorozovski@gmail.com

${ }^{4}$ Старший научный сотрудник сектора археологии и памятниковедения Государственного научного иентра защиты культурного наследия от техногенных катастроф, ORCID 0000-0003-1143-785X, vanhopta@ukr.net ${ }^{5}$ Сотрудник Волынской палеолитической экспедиции, Дубно, Украина, ORCID 0000-0002-5581-3784, duben@ukr.net
} 


\section{О ТЕХНОЛОГИЧЕСКОЙ И ТИПОЛОГИЧЕСКОЙ ЦЕЛОСТНОСТИ КОМПЛЕКСОВ СЕВЕРО-ЗАПАДНОЙ УКРАИНЫ МЕЖДУ 35 И 30 ТЫС. КАЛ. ЛЕТ НАЗАД}

Стоянки Мирогоща I, Грядки, Жорнив и Червоный Каминь расположены в центральной части Волынского лессового плато на северо-западе Украины. Кремневые комплексы стоянок происходят как из раскопок, так и из поверхностных сборов. Эти материалы имеют ряд характеристик, которые традиционно трактуются, как типичные для материалов различных хронологических периодов. Поэтому считалось, что эти коллекции представляют палимпсесты среднего и верхнего палеолита. В 2018 и 2019 годах были получены новые материалы во время полевых исследований стоянки Мирогоща I, а также обработана коллекцияМирогощи I и кремневые комплексы ряда других памятников, которые хранятся в Ровенском областном краеведческом музее.

В результате проведенных исследований можно утверждать, что кремневые комплексы стоянок Мирогоща I, Грядки, Жорнив и Червоный Каминь не являются смешанными и не демонстрируют постепенное развитие индустрий на этой территории от среднего к верхнему палеолиту. Материалы этих памятников демонстрируют одинаковый последовательный набор типологических и технологических черт. Подобные признаки наблюдаются также в кремневых коллекциях памятников Майдан-плато, Иванычи и Липа І. Наиболее вероятно, эти типологические и технологические черты представляют целостный набор особенностей, характерных для периода примерно от 35 до 30 тыс. кал. л. н.

Данные исследования выполнены в рамках международного украино-немецкого археологического проекта «Between East and West. Social networks and environmental conditions before, during and after Last Glacial Maximum in Volhynia, Western Ukraine», на средства фонда научных исследований Германии (Deutsche Forschungsgemeinschaft), грант DFG-392605832.

Ключ е в ы е сло в а: односторонние и двусторонние орудия, радиальные нуклеусы, ториевые нуклеусы, нуклеусы для пластин, острия на пластинах.

\section{References}

Grigoriiev, G. P. 1968. Nachalo verkhnego paleolita i proiskhozhdenie Homo sapiens. Leningrad: Nauka.

Grigoriiev, G. P. 1970. Verkhnii paleolit. Kamennyi vek na territorii SSSR. Materialy i issledovaniia po arkheologii SSSR, 166, p. 4363.

Nuzhnyi, D. Yu. 2015. Verkhnii paleolit zakhidnoi i pivnichnoi Ukrainy (tekhniko-typolohichna variabelnist ta periodyzatsiia). Kyiv: vydavets Oleh Filiuk.

Ostrovskii, M. I., Grigoriiev, G. P. 1966. Lipskaia paleoliticheskaia kultura. Sovetskaia arkheologiia, 4, p. 3-13.

Piasetskyi, V. K. 1999. Paleolit skhidnoi chastyny Volynskoi vysochyny. Vita Antiqua, 2, p. 8-17.

Pyasetskyi, V. K. 1999. Pozdnepaleoliticheskaia stoianka Mirogoshcha I (Pole Votruby). Rosiiskaia arkheologiia, 3, p. 98-107.

Piasetskyi, V. K. 2009. Paleolit Volynskoi vysochyny i Maloho Polissia. Rivne: TOV Druk Volyni.

Rudynskyi, M. Ya. 1952. Dubno-Kremenetska paleolitychna ekspedytsiia. Arkheolohichni pamiiatky URSR, IV, p. 143-154.

Savych, V. P. 1975. Piznopaleolitychne naselennia pivdenno-zakhidnoi Volyni. Kyiv: Naukova dumka.

Sytnyk, O. S. 2010. Lypska piznopaleolitychna kultura: analiz ta interpretatsiia dzherel. Kamiana doba Ukrainy, 13, p. 113-137.

Boëda, E. 1994. Le Concept Levallois: Variabilité des Méthodes. Paris: CNRS Editions.

Buch, M. W., Zöller, L. 1990. Gliederung und Thermolumineszenz-ChronologiederWürmlösse im Raum Regensburg. Eiszeitalter und Gegenwart, 40, p. 63-84.

Juvigné, E. H. \& Wintle, A. G. 1988. A New Chronostratigraphy of the Late Weichselian Loess Units in Middle Europe based on Thermoluminescence Dating. Eiszeitalter und Gegenwart, 38, p. 94-105.

Reimer, P. J., Bard, E., Bayliss, A., Beck, J. W., Blackwell, P. G., Bronk Ramsey, C., Buck, C. E., Cheng, H., Edwards, R. L., Friedrich, M., Grootes, P. M., Guilderson, T. P., Haflidason, H., Hajdas, I., Hatté, C., Heaton, T. J., Hoffmann, D. L., Hogg, A. G., Hughen, K. A., Kaiser, K. F., Kromer, B., Manning, S. W., Niu, M., Reimer, R. W., Richards, D. A., Scott, E. M., Southon, J. R., Staff, R. A., Turney, C. S. M, \& van der Plicht, J. 2013. IntCal 13 and Marine 13 radiocarbon age calibration curves 0-50,000 years cal BP. Radiocarbon, 55, p. 1869-1887.

Sprafke, T. 2015. Löss in Niederösterreich. Archiv quartärer Klima- und Landschaftsveränderungen.Würzburg: Würzburg University Press.

Weninger, B., Jöris, O. \& Danzeglocke, U. 2014. CalPal-2014. Cologne Radiocarbon Calibration \& Palaeoclimate Research Package, http://www.calpal.de, (access 09 November 2016). 